\title{
A Literature Review on the Studies of Internet Retailing Management
}

\author{
Tao Zhang, Guijun Zhuang, Yuanyuan Huang \\ School of Management, Xi'an Jiaotong University, Xi'an, China \\ E-mail:flinkzt@gmail.com,zhgj@mail.xjtu.edu.cn,phoebe.hyy@gmail.com \\ Received October 26, 2009; revised November 23, 2009; accepted December 22, 2009
}

\begin{abstract}
This paper reviewed the studies of Internet retailing management. It found that, in general, most of the papers on the topic took focus on Internet retailing strategy and online merchandise management. Specifically, it drawn following conclusions: First, there were six major incentives for firms to adopt Internet retailing, including improving internal communication, improving operational efficiency, facing competition, enhancing customer services, reaching out to a wider audience, and improving relations with suppliers. Second, cost of Internet trading and consumer preference were negatively, while status of Internet retailing strategy, technology capability, Internet communication preference, Internet marketplace, and market development opportunity were positively, affect firms to adopt Internet retailing. Third, market positioning, business model, estimation of the market size, Internet-based innovative application, and strong brand of website were the key factors for the success of an online retailing website. Fourth, cross-channel conflict might be reduced by reconstructing the business process or adjusting the pricing strategy, while Internet retailing inventory might be improved by firms' zero inventory policy, in-stock inventory policy, and dynamic inventory policy. Finally, a firm's quality of logistics and delivery could be increased by high-value-package strategy and emergency transshipments. Implications of these conclusions were suggested.
\end{abstract}

Keywords: Internet Retailing, Internet Retailing Strategy, Online Merchandise Management, Online Store Management

\section{Introduction}

Retailing is the set of business activities that adds value to the products and services sold to consumers for their personal or family use [1]. Internet retailing is the retailing business on the Internet [2]. That is to say, on one side, providers sell products or provide services on their online website; on the other side, consumers buy products or services by accessing such website via connected computers (i.e., Internet). Digital products will be delivered to customers by Internet directly and non-digital products will be delivered by logistics.

Doherty and Ellis-Chadwick classified the studies of Internet retailing into three categories [3]. The first category is the studies from customer perspective, taking the focus on customer online purchasing behavior and psychology. The second category is the studies from retailer (i.e., company) perspective, taking the focus on the re-

The financial support of a NSF program (No. 70972102) from National Natural Science Foundation of China is gratefully notified. tailing management, such as business model design and online store management. The third category is those from technology perspective, taking the focus on the innovation of emerging IT for the online retailing management. For example, Flash can be used to enhance the display of products.

This paper will review the studies of the second category for two reasons. Firstly, Internet retailing is developing rapidly, and research on Internet retailing management has important theoretical and practical significance [4]. In the market, failed and successful websites coexists. What factors affect the failures and successes of running Internet retailing? How should a firm design their business model and evaluate it? Studies on these questions are far from enough. Therefore, a review on the studies about these questions will expand the retailing theory in the cyber world and guide the management practice of Internet retailing. Secondly, no detailed review on Internet retailing management has been found in the literature. A detailed review on the studies of Internet consumer behavior, the first category, has been done by 
Cheung, Chan and Limayem [5]. Although Doherty and Ellis-Chadwick [3] have reviewed the studies of Internet retailing (the second category) as a whole, their review for the studies of Internet retailing management is lack of details. To guide the future studies of Internet retailing management, it is necessary to review the studies on the topic in more depth and with more details.

The paper is organized as follows: Section 1 is a framework to summarize the papers. Section 2 reviews the papers on Internet retailing strategy. Section 3 reviews the papers on online merchandise management. Section 4 reviews the papers on online store management. Conclusions and implications are given at the final section.

\section{Paper Selection and Classification}

We used the term "Internet retailing" and "e-tailing" to search the papers in the EBSCO, Proquest and ScienceDirect. 125 papers with full text were found. Among those papers, 86 in the perspective of consumer behavior and technology were weeded out, and 39 in the retailer perspective left, ranging from 1996 to 2007 . We didn't use the term "B2C" to search because it is a general concept which refers to all the business activity between buyers and sellers in the cyber world, such as retailing, intermediary, and infomediary.

There are three areas for retailing research, namely retailing strategy, merchandise management, and store management [1]. The retailing strategy is the basis of merchandise and store management, while merchandise and store management are the implementation of retailing strategy. Internet changes the way of retailing, but does not change the retailing itself [6]. So, we use this framework to organize the papers we selected. As shown in Table 1, Internet retailing strategy received more attention, and then online merchandise management. Few studies have been found exploring the issues on online store management.

\section{Internet Retailing Strategy}

Most of the early studies in this area were descriptive or assumptive. Many researchers believed that, by taking advantage of Internet such as $24 \times 7$ online and buying at home, Internet retailing is superior to traditional retailing. They predicted Internet retailing would replace traditional retailing [7-9]. However, this was wrong. Doherty et al. reported that few companies had set up their own online retailing website in 1999 [10]. Hart, Doherty, Kotzab, Madlberger and Ellis-Chadwick found that Internet usage among companies was at the early stage, i.e., firms' websites were more for the informational purpose than for the trade function $[11,12]$. Chen and Leteney found that many traditional retailers had run both online and offline shops at the same time [13]. In brief, Internet retailing didn't flourish and traditional retailing was not replaced by Internet retailing.

As a result, researchers began to pay close attention to the following four questions: what are the incentives for a firm to adopt Internet? What factors affect a firm's Internet adoption? How a firm should design its business model and marketing strategy based on Internet? How a firm should manage the online shop and offline shop at the same time?

\subsection{Incentives for Adopting Internet}

Seven papers about this sub-topic were identified from the three databases (see Table 1). These papers proposed and tested two internal and four external incentives.

Two internal incentives were found to have positive impact on firms' intention of Internet adoption. The first is improving internal communication $[13,14]$. In daily work, employees have to communicate frequently to coordinate their works with others. Internet is capable of transmitting all kinds of information such as instant informal messages, formal documents, sound, and video at the same time with one integrated computer-based platform. Therefore, if a company wants to improve its internal communication, the tools of Internet-based communication will be the first choice. The second internal incentive is improving operational efficiency [15]. Internet-based information system (i.e., information system, such as ERP, Lotus Notes) is powerful for enhancing work efficiency, reducing cost, and simplifying workflow. It can be used to replace manual operations in daily work. Therefore, if the headquarter of a company wants to improve the operational efficiency, it is likely to adopt Internet-based information system.

Four external incentives were found to have positive impact on firms' intention of Internet adoption. The first is facing competition, i.e., a firm feels a threat from competitor's website $[10,15,16]$. In the competitive market, every company would try its best to gain competitive advantage. If a company have taken the advantage of Internet (e.g., setting up websites or adopting MIS), others are likely to feel a threat and follow the "me too" strategy to avoid falling behind. The second incentive is enhancing customer services $[11,12,15]$. Winning customers is one of the most important goals for a company. Internet-based website can play a role in winning customers. Specifically, customers may use website to search products, get related information, complain, and communicate with others. These activities are all helpful for a company to win customers by engaging in Internet retailing. The third incentive is reaching out to a wider audience $[10,16]$. Internet is an open system. It eliminates the borders of physical regions. With search engine 
Table 1. Paper summary.

\begin{tabular}{|c|c|c|c|c|}
\hline Areas & Focal questions & $\begin{array}{l}\text { Number } \\
\text { of Papers }\end{array}$ & Methodology & Conclusions \\
\hline \multirow{4}{*}{$\begin{array}{l}\text { Internet re- } \\
\text { tailing strat- } \\
\text { egy }\end{array}$} & $\begin{array}{l}\text { Incentives for } \\
\text { adopting Internet }\end{array}$ & 8 & $\begin{array}{l}\text { Quantity analysis } \\
\text { based on statis- } \\
\text { tics. }\end{array}$ & $\begin{array}{l}\text { Six incentives, i.e. improving internal communication, } \\
\text { improving operational efficiency, facing competition, } \\
\text { enhancing customer services, reaching out to a wider } \\
\text { audience and improving relations with suppliers, have } \\
\text { positive impact on the intention of adopting Internet. }\end{array}$ \\
\hline & $\begin{array}{l}\text { Factors affecting } \\
\text { the Internet adop- } \\
\text { tion }\end{array}$ & 6 & $\begin{array}{l}\text { Quantity analysis } \\
\text { based on statis- } \\
\text { tics and quality } \\
\text { study based on } \\
\text { case. }\end{array}$ & $\begin{array}{l}\text { Two factors, i.e. cost of Internet trading and consumer } \\
\text { preference, have negative impact on Internet retailing } \\
\text { adoption. Five factors, i.e. status of Internet retailing } \\
\text { strategy, technology capability, Internet communication } \\
\text { preference, Internet marketplace and market develop- } \\
\text { ment opportunity, have positive impact on Internet re- } \\
\text { tailing adoption. }\end{array}$ \\
\hline & $\begin{array}{l}\text { Online business } \\
\text { model and mar- } \\
\text { keting strategy }\end{array}$ & 6 & $\begin{array}{l}\text { Case study and } \\
\text { paper research. }\end{array}$ & $\begin{array}{l}\text { Five factors, i.e. market positioning, business model, } \\
\text { estimation of the market size, Internet- based innovative } \\
\text { application and strong brand of website, are the key for a } \\
\text { successful online retailing website. And the business } \\
\text { model and marketing strategy should be designed ac- } \\
\text { cording to product purchasing frequency, product tangi- } \\
\text { ble or intangible and product differentiation. }\end{array}$ \\
\hline & $\begin{array}{l}\text { Multi-channel } \\
\text { management }\end{array}$ & 7 & Game models. & $\begin{array}{l}\text { Cross-channel conflict can be reduced in two ways. One } \\
\text { is "integration" perception, which is aimed at recon- } \\
\text { structing the business process; the other is "adjustment" } \\
\text { perception, which is aimed at adjusting the pricing } \\
\text { strategy of the two retailing channels. }\end{array}$ \\
\hline \multirow{2}{*}{$\begin{array}{l}\text { Online mer- } \\
\text { chandise } \\
\text { management }\end{array}$} & $\begin{array}{l}\text { Merchandise in- } \\
\text { ventory strategy }\end{array}$ & 4 & Game models. & $\begin{array}{l}\text { Zero inventory policy, in-stock inventory policy and } \\
\text { dynamic inventory policy, are able to reduce Internet } \\
\text { retailing inventory cost effectively. }\end{array}$ \\
\hline & $\begin{array}{l}\text { Merchandise lo- } \\
\text { gistics }\end{array}$ & 4 & $\begin{array}{l}\text { Quantity statis- } \\
\text { tics and game } \\
\text { models. }\end{array}$ & $\begin{array}{l}\text { High-value-package strategy and emergency transship- } \\
\text { ments are able to enhance the quality of logistics and } \\
\text { delivery effectively. }\end{array}$ \\
\hline $\begin{array}{l}\text { Online store } \\
\text { management }\end{array}$ & No focal questions & 4 & Paper research & No focus explicitly formed. \\
\hline
\end{tabular}

(e.g., Google or Yahoo) or catalog, it is easier for a customer to search things that he wants. Internet-based web site can help companies to win greater amount of and more remote customers. The fourth incentive is improving relations with suppliers $[15,17]$. It is very important for a company to keep close relationships with its sup-pliers given the importance of the supply chain in firm success. Many MIS (e.g., ERP, MRPII) are design to meet such needs. Therefore, those who want to improve relations with their suppliers will have higher intention to adopt Internet-based information system.

\subsection{Factors Affecting the Internet Retailing Adoption}

Six papers about this topic were found in the three databases, proposing and testing even factors related to the aspects of company, customer and cyber world (see Table 1).

Three company factors, identified by previous studies, were found having different impact on firms' adoption of Internet retailing. Cost of Internet trading is negatively, status of Internet retailing strategy and technology capability are positively, related to firms' adoption of Internet retailing. If the costs of Internet trading such as logistics cost, organization expense, and operation cost are so high that the adoption of Internet retailing will reduce a company's profit, the company will loss it's enthusiasm for the adoption [18]. Status of Internet retailing strategy refers to the support from headquarters (i.e., general manager or chairman of the board) $[18,19]$. A headquarter has the right of using the resources such as money and technician in a company. If the headquarter supports the Internet retailing, it will provide the resources neces- 
sary for the Internet retailing adoption. The Internet retailing adoption will go smoothly and deeply. Technology capability of a firm will affect firm's web page quality, speed of accessing, and online security [18-20]. In other words, the higher a company's technology capability, the higher the website quality is, and the better the Internet retailing adoption.

Of the two customer factors identified by previous studies, consumer preference for traditional offline shopping was found having a negative, while Internet communication preference was found having a positive, impact on firms' adoption of Internet retailing [18]. Many consumers may think Internet retailing is lack of touching products, so they prefer offline shopping to online shopping. This will discourage a firm to adopt Internet retailing. Internet communication are more preferred as more and more people are living with Internet [18]. Word-of-mouth is more effective for Internet retailing than for other tools of communication. These will help a firm to adopt Internet retailing.

Two cyber world factors have positive impact on the Internet retailing adoption. The first is Internet marketplace, i.e. market management and market rules [18,19]. Good cyber market management and rules are able to create a good cyber trading environment. A good environment is helpful for a company to run a retailing website efficiently, making it more likely to adopt Internet retailing. The second is market development opportunity i.e., the sales that a firm can archive through Internet retailing $[16,18]$. The more sales and profit a company can get through Internet retailing, the more likely and to higher degree that the company would adopt Internet retailing.

\subsection{Online Business Model and Marketing Strategy}

Online business model and marketing strategy refers to the following three questions, i.e., what to sell, whom to sell, and how to sell online. Six papers on these questions were found in the databases (see Table 1).

Some researchers tried to figure out the key points of successful online retailing websites. Ring and Tigert suggested that market positioning, business model, and estimation of the market size are the three key factors for a successful online retailing website [21]. These factors can be used by a company to obtain competitive advantage and survive in the market. Kotha found that the Internet-based innovative application such as online Flash games and strong brand of website are effective for attracting consumers [22]. Therefore, applying new techniques and building a good website reputation are key factors for a successful online retailing website.

Other researchers studied the business model and marketing strategy. For example, Peterson et al. pro- posed that business model and marketing strategy should be designed according to the three aspects of products, i.e. purchasing frequency, tangible or intangible, and differentiation [23]. For instance, a firm should choose a strategy of online retailing, high price, and steep price cuts for electronic fashion magazine (the frequently purchased, intangible, and high differentiation products), while for gold bar (the infrequently purchased, tangible, and low differentiation products), the firm should try a strategy of offline retailing with advertising online and stable price.

\subsection{Multi-Channel Management}

Multi-channel means a company runs online and offline retailing channel at the same time, i.e., clicks-bricks $[13,24,25]$. As shown in Table 1, seven papers on this topic were found. These papers focused on how to reduce the cross-channel conflict, including Internet and traditional retailing contesting for money and equipment inside and for markets and suppliers outside [13,24,26].

Some researchers adopted the perception of "integration". They tried to reconstruct the business process to reduce the conflict. For example, Chen, Enders, Jelassi and Leteney [13,24] analyzed the business process of Internet retailing and traditional retailing respectively from the perspective of merchandise transferring. They found that the supply, purvey of information, communication, logistics, and transaction processes can be combined or partially combined. For instance, the supply of Internet retailing and traditional retailing, the advertisements and part of information purvey process, can be combined into one. This will reduce the conflict between a firm's Internet and traditional retailing.

Other researchers adopted the perception of "adjustment". They tried to reduce conflict through adjusting the pricing strategy of the two retailing channels. Generally, the online price is $14 \%$ lower than the offline price, so it is believed to be the origin of the cross-channel conflict [27]. Yao and Liu [6,26] analyzed the conflict by modeling with game theory. They found an equilibrium price exists between two retailing channels. This price is close to the offline price, but much higher than the online price. It will increase the traditional retailing sales but reduce the Internet retailing sales. However, the increase will be greater than the reduction, so the total sales will be greater.

\subsection{Summary}

To sum four conclusions can be drawn from the above review. Firstly, there are six incentives for firms' intention of adopting Internet retailing, i.e., improving internal communication, improving operational efficiency, facing competition, enhancing customer services, reaching out 
to a wider audience, and improving relations with suppliers. Secondly, two factors, namely Internet trading cost and consumer preference for offline shopping, have negative impact on Internet retailing adoption. Five factors, i.e., status of Internet retailing strategy, technology capability, Internet communication preference, Internet marketplace, and market development opportunity, have positive impact on Internet retailing adoption. Thirdly, market positioning, business model, estimation of the market size, Internet-based innovative application, and strong brand of website are the key factors for a successful online retailing website, and business model and marketing strategy should be designed according to product purchasing frequency, product tangible or intangible, and product differentiation. Fourthly, cross-channel conflict can be reduced in two ways, i.e., "integration" perception which is aimed at reconstructing the business process and "adjustment" perception which is aimed at adjusting the pricing strategy of the two retailing channels.

\section{Online Merchandise Management}

Traditional merchandise management is the process by which a company attempts to offer the right quantity of the right merchandise in the right place at the right time in order to achieve the company's financial goals [1]. Online merchandise management, similar to that of traditional retailing, is a management process of merchandise purchasing, sorting, and transporting. Eight papers were found on this topic (see Table 1), taking focus on inventory management and logistics or delivery management.

Researchers found that redesigning inventory policy for Internet retailing is able to reduce inventory cost effectively. Combining the zero inventory policy with the in-stock inventory policy, Bailey and Rabinovich proposed a dynamic inventory policy by applying a feature of Internet retailing and the asynchrony of goods payment and procurement [28]. Zhao and Cao studied the situations under which the zero inventory policy and in-stock inventory policy should be applied [29]. They found that the zero-inventory policy were preferred under a positive relationship between reservation price and impatience for delivery, whereas the positive-inventory policy is preferred when these two variables are independent of each other. Furthermore, a more rapid expansion of market is a favorable condition for the zero inventory policy [29].

Other researchers found that some new strategies are able to enhance the quality of logistics and delivery. Rabinovich and Bailey split the quality of logistics and delivery into three dimensions, namely availability, timeliness, and reliability [30]. They proposed that, because more attention is paid to high value package, increasing the value of package is able to ensure the quality of lo- gistics and delivery from above three dimensions [30]. Elliot found that emergency transshipments could improve the quality of logistics and delivery [31]. Du et al. [32] developed a three-phase solution strategy (i.e., initial-routes formation, inter-routes improvement, and intra-route improvement) to ensure the quality of logistics and delivery. The three-phase solution strategy was found being significantly better than conventional strategy in travel distance and delivery time.

In summary, inventory policies such as zero inventory policy, in-stock inventory policy, and dynamic inventory policy, are able to reduce Internet retailing inventory cost effectively. Some strategies such as high-value-package strategy, and emergency transshipments, are able to enhance the quality of logistics and delivery effectively.

\section{Online Store Management}

Traditional store management is aimed at enhancing utilization of the fixed assets and work efficiency [1]. Similarly, Internet retailing store management is aimed at enhancing the hits of web pages and work efficiency $[33,34]$. As shown in Table 1, four papers were found on this sub-topic.

Katerattanakul and Keng [33] proposed a framework for developing web pages, mapping the 27 factors of online store image on the physical store image. For example, the website response time is mapped on the aisle placement and width of physical shop. King and Liou [34] proposed a framework for evaluating the performance of retailing website. The framework consists of two facets of indicators, the user facet and the business facet. The user facet is made up with availability, customer loyalty, etc. And the business facet is made up with strategic position, complementarities, etc. Moreover, Alexis, Noreen, and Jiang [35,36] reviewed the extant IT, such as PC, PDA, and mobile phone. They predicted that more and more new IT will be introduced into Internet retailing. For example, the virtual reality is in prospect, giving customers a better shopping experience.

\section{Conclusions and Implications}

This paper reviewed the studies of Internet retailing management. We found that most of the papers focused on Internet retailing strategy management and online merchandise management. Following conclusions may be drawn. Firstly, there are six incentives for firms' intention of adopting Internet retailing, i.e., improving internal communication, improving operational efficiency, facing competition, enhancing customer services, reaching out to a wider audience, and improving relations with suppliers. Secondly, two factors (cost of Internet trading and consumer preference) have negative impact on Internet retailing adoption while five factors (status of 
Internet retailing strategy, Internet communication preference, etc.) have positive impact on Internet retailing adoption. Thirdly, five factors (market positioning, Internet-based innovative application, etc.) are the key for a successful online retailing website, and online business model and marketing strategy should be designed according to product purchasing frequency, product tangible or intangible, and product differentiation. Fourthly, the cross- channel conflict may be reduced effectively by reconstructing the business process or adjusting the pricing strategy. Fifthly, zero inventory policy, in-stock inventory policy, and dynamic inventory policy are able to reduce Internet retailing inventory cost. Finally, highvalue-package strategy and emergency transshipments are able to enhance the quality of logistics and delivery.

These conclusions have useful implications for companies. Firstly, obtaining as much attention as possible from its headquarter, lowering the trading cost, and improving Internet retailing related technology are the silver bullets for a firm to adopt and improve its Internet retailing. Secondly, the Internet retailing business model and marketing strategy should be designed by the characteristics of products. Reconstructing the business process and adjusting the pricing strategy are the two ways to reduce the cross-channel conflict. Thirdly, in order to reduce the cost of inventory and guarantee the quality of logistics and delivery, a company should adopt new inventory policy and logistics strategy such as dynamic inventory policy and high-value-package strategy according to the environment and situations.

\section{References}

[1] M. Levy and B. A. Weitz, "Retailing management," Richard D. Irwin, Inc. Massachusetts, 2006.

[2] B. Rosenbloom, "Marketing channels: A management view," 6th edition, The Dryden Press. New York, 1999.

[3] N. F. Doherty and F. E. Ellis-Chadwick, "New perspectives in Internet retailing: A review and strategic critique of the field," In International Journal of Retail \& Distribution Management, Vol. 34, No. 4-5, pp. 411-428, 2006.

[4] D. Grewal, G. R. Iyer and M. Levy, "Internet retailing: Enablers, limiters and market consequences," In Journal of Business Research, Vol. 57, No. 7, pp. 703-713, 2004.

[5] M. K. C. Cheung, W. W. G. Chan and M. Limayem, "A critical review of online consumer behavior: Empirical research," In Journal of Electronic Commerce in Organizations, Vol. 3, No. 4, pp. 1-19, 2005.

[6] D.-Q. Yao and J. J. Liu, "Channel redistribution with direct selling," In European Journal of Operational Research, Vol. 144, No. 3, pp. 646-658, 2003.

[7] W. R. Swinyard, "Retailing trends in the USA: Competition, consumers, technology and the economy," In International Journal of Retail \& Distribution Management, Vol. 25, No. 8-9, pp. 244-256, 1997.
[8] K. T. Rosen and A. L. Howard, "E-retail: Gold rush or fool's gold?" In California Management Review, Vol. 42, No. 3, pp. 72-100, 2000.

[9] J. Drennan and J. R. McColl-Kennedy, "The relationship between Internet use and perceived performance in retail and professional service firms," In Journal of Services Marketing, Vol. 17, No. 3, pp. 295-311, 2003.

[10] N. F. Doherty, F. Ellis-Chadwick and C. A. Hart, "Cyber retailing in the UK: The potential of the Internet as a retail channel," In International Journal of Retail \& Distribution Management, Vol. 27, No. 1, pp. 22-36, 1999.

[11] C. Hart, N. Doherty and F. Ellis-Chadwick, "Retailer adoption of the Internet: Implications for retail marketing," In European Journal of Marketing, Vol. 34, No. 8, pp. 954-974, 2000.

[12] H. Kotzab and M. Madlberger, "European retailing in e-transition?" In International Journal of Physical Distribution \& Logistics Management, Vol. 31, No. 6, pp. 440462, 2001.

[13] S. Chen and F. Leteney, "Get real! Managing the next stage of Internet retail," In European Management Journal, Vol. 18, No. 5, pp. 519-528, 2000.

[14] J. A. A. Sillince, S. Macdonald, B. Lefang and B. Frost, "Email adoption, diffusion, use and impact within small," In International Journal of Information Management, Vol. 18, No. 4, pp. 231-243, 1998.

[15] M. D. Elizabeth and J. G. David, "An exploratory comparison of electronic commerce adoption in large and small enterprises," In Journal of Information Technology, Vol. 17, No. 3, pp. 133-147, 2002.

[16] N. Whittaker, "Why marketing, not technology, drives net retail," In Marketing, 26, 1999.

[17] N. M. Levenburg, "Delivering customer value online: An analysis of practices, applications, and performance," In Journal of Retailing and Consumer Services, Vol. 12, No. 5, pp. 319-331, 2005.

[18] N. Doherty, F. Ellis-Chadwick and C. Hart, "An analysis of the factors affecting the adoption of the Internet in the UK retail sector," In Journal of Business Research, Vol. 56, No. 11, pp. 887-897, 2003.

[19] M. K. O. Lee and C. M. K. Cheung, "Internet retailing adoption by small-to-medium sized enterprises (SMEs): A multiple-case study," In Information Systems Frontiers, Vol. 6, No. 4, pp. 385-397, 2004.

[20] D. Pavitt, "Retailing and the super high street: The future of the electronic home shopping industry," In International Journal of Retail \& Distribution Management, Vol. 25, No. 1, pp. 38-43, 1997.

[21] J. R. Lawrence and J. T. Douglas, "Viewpoint: The decline and fall of Internet grocery retailers," In International Journal of Retail \& Distribution Management, Vol. 29, No. 6-7, pp. 266-273, 2001.

[22] S. Kotha, "Competing on the Internet: The case of Amazon.com," In European Management Journal, Vol. 16, No. 2, pp. 212-222, 1998.

[23] A. R. Peterson, S. Balasubramanian, and B. J. Bronnenberg, "Exploring the implications of the Internet for con- 
sumer marketing," In Journal of the Academy of Marketing Science, Vol. 25, No. 4, pp. 329-346, 1997.

[24] A. Enders and T. Jelassi, "The converging business models of Internet and bricks-and-mortar retailers," In European Management Journal, Vol. 18, No. 5, pp. 542-550, 2000.

[25] L. P. A. Simons, C. Steinfield and H. Bouwman, "Strategic positioning of the Web in a multichannel market approach," In Internet Research, Vol. 12, No. 4, pp. 339347, 2002.

[26] D.-Q. Yao and J. J. Liu, "Competitive pricing of mixed retail and e-tail distribution channels," In Omega, Vol. 33, No. 3, pp. 235-247, 2005.

[27] F.-F. Tang and X. Xing, "Will the growth of multi-channel retailing diminish the pricing efficiency of the web?" In Journal of Retailing, Vol. 77, No. 3, pp. 319-333, 2001.

[28] J. P. Bailey and E. Rabinovich, "Internet book retailing and supply chain management: An analytical study of inventory location speculation and postponement," In Transportation Research Part E: Logistics and Transportation Review, Vol. 41, No. 3, pp. 159-177, 2005.

[29] H. Zhao and Y. Cao, "The role of e-tailer inventory policy on e-tailer pricing and profitability," In Journal of Retailing, Vol. 80, No. 3, pp. 207-219, 2004.

[30] E. Rabinovich and J. P. Bailey, "Physical distribution service quality in Internet retailing: Service pricing, transaction attributes, and firm attributes," In Journal of Operations Management, Vol. 21, No. 6, pp. 651-672, 2004.

[31] E. Rabinovich, "Consumer direct fulfillment performance in Internet retailing: Emergency transshipments and demand dispersion," In Journal of Business Logistics, Vol. 26, No. 1, pp. 79-112, 2005.

[32] T. C. Du, E. Y. Li and D. Chou, "Dynamic vehicle routing for online B2C delivery," In Omega, Vol. 33, No. 1, pp. 33-45, 2005

[33] P. Katerattanakul and K. Siau, "Creating a virtual store image," In Communications of the ACM, Vol. 46, No. 12, pp. 226-232, 2003.

[34] S. F. King and J.-S. Liou, "A framework for Internet channel evaluation," In International Journal of Information Management, Vol. 24, No. 6, pp. 473-488, 2004.

[35] A. K. J. Barlow, N. Q. Siddiqui and M. Mannion, "Developments in information and communication technologies for retail marketing channels," In International Journal of Retail \& Distribution Management, Vol. 32, No. 2-3, pp. 157-163, 2004.

[36] Z. Jiang, W. Wang and I. Benbasat, "Multi-media-based interactive advising technology for online consumer decision support," In Communications of the ACM, Vol. 48, No. 9, pp. 92-98, 2005. 